\title{
PEMANFAATAN JERINGAU MERAH (Acorus sp) SEBAGAI PENGGANTI ANTIBIOTIKA TERHADAP PERFORMA AYAM BROILER YANG DIINFEKSI Salmonella typhimurium
}

\author{
TRIBUDI, Y. A., A. TOHARDI, DAN Y. ROHAYETI \\ Program Studi Peternakan Fakultas Pertanian Universitas Tanjungpura \\ e-mail: yuliariftribudi@gmail.com
}

\begin{abstract}
ABSTRAK
Tujuan penelitian ini untuk mengetahui pengaruh pemberian ekstrak jeringau merah dalam air minum terhadap performa ayam broiler. Penelitian menggunakan 25 ekor ayam broiler strain Copp produksi PT. Japfa Comfeed Indonesia yang dipelihara sejak day old chicks sampai umur 30 hari. Penelitian menggunakan rancangan acak lengkap dengan 5 perlakuan dan 5 ulangan. Perlakuan dalam penelitian ini terdiri dari $\mathrm{P}_{1:}$ Ayam tanpa diinfeksi Salmonella typhimurium dan tanpa pemberian ekstrak jeringau merah (kontrol positif); $\mathrm{P}_{2}:$ yam diinfeksi Salmonella typhimurium, tanpa pemberian ekstrak jeringau merah (kontrol negatif); $\mathrm{P}_{3}$ : Ayam diinfeksi Salmonella typhimurium + ekstrak jeringau merah 0,5 ml/kg BB; $\mathrm{P}_{4}$ : Ayam diinfeksi Salmonella typhimurium + ekstrak jeringau merah $1 \mathrm{ml} / \mathrm{kg} \mathrm{BB}$ dan $\mathrm{P}_{5}$ : Ayam diinfeksi Salmonella typhimurium + antibiotik tetrasiklin 0,02\% BB. Data yang diperoleh dianalisis dengan menggunakan analisis sidik ragam. Hasil penelitian menunjukkan bahwa pemberian ekstrak jeringau merah pada air minum tidak berpengaruh $(\mathrm{P}>0,05)$ terhadap konsumsi pakan, pertambahan berat badan dan konversi ransum pada ayam broiler yang diinfeksi Salmonella typhimurium. Ekstrak jeringau merah taraf $1 \mathrm{ml} / \mathrm{kg}$ BB. Disimpulkan bahwa pemberian Ekstrak jeringau merah taraf $1 \mathrm{ml} / \mathrm{kg}$ BB dapat digunakan sebagai pengganti antibiotik karena tidak mempengaruhi pertambahan berat badan dan efisiensi pengunaan pakan.
\end{abstract}

Kata kunci: antibakteri, ayam broiler, antibiotika, performans

\section{RED JERINGAU (Acorus sp) AS ANTIBIOTIC SUBSTITUTE ON THE BROILER PERFORMANCES INFECTED WITH Salmonella typhimurium}

\begin{abstract}
This study aims to determine the effect of adding red jeringau extract through drinking water on broiler performances. This study used 25 Copp strain-broilers produced by PT. Japfa Comfeed Indonesia, which were maintained since day old chicks until 30 days old. This study used five treatments and five replications. The treatment in this study as of P1: chickens not infected with Salmonella typhimurium and not given red jeringau extract (positive control); P2: chickens infected with Salmonella typhimurium, without the extract red jeringau (negative control); P3: chickens infected with Salmonella typhimurium + extract red jeringau $0.5 \mathrm{ml} / \mathrm{kg}$ body weight; P4: chickens infected with Salmonella typhimurium+red jeringau extract $1 \mathrm{ml} / \mathrm{kg}$ body weight and P5: chickens infected with Salmonella typhimurium + 0.02\% body weight tetracycline antibiotics. The data were analyzed using analysis of variance. The result show that red jeringau extract in drinking water had not significant effect $(\mathrm{P}>0.05)$ on feed consumption, body weight gain, and feed conversion in broiler as infected with Salmonella typhimurium. It can be concluded that red jeringau extract at $1 \mathrm{ml} / \mathrm{kg}$ body weight can be used as a substitute for antibiotics because has not effect on the body weight gain and feed efficiency.
\end{abstract}

Keywords: antibacterial, broiler, antibiotics, performance 


\section{PENDAHULUAN}

Indonesia banyak tanaman yang berpotensi untuk dijadikan imbuhan pakan diantarnya adalah tanaman jeringau merah. Jeringau merah (Acorus sp) dari famili Araceae merupakan jeringau yang tumbuh liar di hutan Kalimantan Barat terdapat tanaman yang secara empiris digunakan oleh suku Dayak untuk pengobatan typhus dan demam berdarah. Tanaman ini mempunyai rimpang yang beraroma kuat dengan bentuk tanaman seperti rumput dan tanah basah untuk pertumbuhannya. Pengujian awal yang dilakukan oleh Purwaningsih (2009) memperlihatkan ekstrak rimpang jeringau merah dapat menghambat pertumbuhan bakteri Salmonella typhosa.

Industri perunggasan telah lama menggunakan antibiotik yang bertujuan untuk memacu pertumbuhan ayam dan control terhadap penyakit (Donado-Godoy et al. 2012) tetapi penggunaan antibiotik menimbulkan efek keamanan pangan akibat adanya residu dalam produk unggas sehingga dapat menyebabkan resistensi antibiotik (Musa et al. 2009) apabila terkonsumsi oleh manusia, karena dapat menyebabkan efek resistensi pada bakteri yang bersifat infectious bagi manusia. Salah satu kendala yang dihadapi dalam pemeliharaan ayam broiler sangat rentan terhadap penyakit diantaranya penyakit salmonellosis. Penyakit ini bersifat infeksius dan septikemik yang disebabkan oleh bakteri gram negatif seperti Salmonella typhimurium dan Salmonella enteritidis (Im et al., 2015). Oleh karena itu, keberhasilan industri ayam tergantung dengan pengendalian Salmonella sp. pada peternakan ayam (Gama et al. 2003).

Adanya pembatasan pemberian antibiotik dan munculnya resistensi terhadap antibiotik, maka penggunaan antibiotic alami yang tidak menimbulkan efek bahaya jangka panjang bagi kesehatan. (Perić et al. 2009). Antibiotik alami yang dapat digunakan meliputi tanaman herbal, spices (rempah-rempahan) ataupun ekstrak komponen aktif yang terkandung di dalam tanaman. Komponen aktif tersebut telah diketahui mempunyai aktivitas anti-mikroba, antifungi dan aktivitas antioksidan (Windisch et al., 2007) salah satunya adalah jeringau merah (Acorus $s p$ ). Penelitian penggunaan antibakteri alami ekstrak jeringau merah (Acorus sp) perlu dilakukan pada Salmonella typhimurium, diharapkan dapat meningkatkan performa ayam broiler sehingga dihasilkan produk unggas yang sehat tanpa residu antibiotika dan aman dikonsumsi manusia.

\section{MATERI DAN METODE}

\section{Materi}

Penelitian menggunakan 25 ekor ayam pedaging strain Copp diproduksi PT. Japfa Comfeed Indonesia yang dipelihara sejak Day Old Chicks sampai umur 30 hari dengan pakan yang digunakan merupakan pakan komersial. Penelitian dilakukan di Laboratorium Program Studi Peternakan Fakultas Pertanian Universitas Tanjungpura.

\section{Pembuatan ekstrak jeringau merah}

Jeringau merah segar bagian rimpang diperoleh dari hutan Kalimantan Barat kemudian dipotong tipis-tipis dan dilayukan di dalam ruang kaca yang tidak terkena sinar matahari langsung lalu dioven pada suhu $30^{\circ} \mathrm{C}$ selama 36 jam. Rimpang jeringau merah yang telah dikeringkan kemudian digiling untuk menghasilkan tepung jeringau merah. Ekstrasi sokletasi menggunakan pelarut organik (methanol) 70\% dengan perbandingan tepung rimpang jeringau merah $50 \mathrm{~g}$ dan ethanol 750 ml. Tepung rimpang jeringau merah ditempatkan dalam kertas saring dan dimasukan dalam alat soklet lalu dilakukan penyaringan sampai tetesan siklus sampai jernih

\section{Perlakuan}

Penelitian ini menggunakan rancangan acak lengkap dengan 5 perlakuan dan 5 kali ulangan. Perlakuan dalam penelitian ini terdiri dari $\mathrm{P}_{1}$ : ayam tanpa diinfeksi Salmonella typhimurium dan tanpa pemberian ekstrak jeringau merah (kontrol positif); $\mathrm{P}_{2}$ : ayam diinfeksi Salmonella typhimurium, tanpa pemberian ekstrak jeringau merah (kontrol negatif); $\mathrm{P}_{3}$ : ayam diinfeksi Salmonella typhimurium + ekstrak jeringau merah 0,5 $\mathrm{ml} / \mathrm{kg} \mathrm{BB} ; \mathrm{P}_{4}$ : ayam diinfeksi Salmonella typhimurium + ekstrak jeringau merah $1 \mathrm{ml} / \mathrm{kg}$ BB dan $\mathrm{P}_{5}$ : ayam diinfeksi Salmonella typhimurium + antibiotik tetrasiklin $0,02 \% \mathrm{BB}$.

\section{Variabel pengamatan}

1. Konsumsi pakan adalah jumlah pakan yang diberikan dikurangi dengan sisa pakan sisa dan dihitung tiap hari selama penelitian.

Konsumsi pakan (g/ekor) = pakan diberikan pakan sisa

2. Pertambahan berat badan (PBB) adalah berat badan ayam saat dipanen dikurangi berat badan awal dibagi lamanya pemeliharaan.

PBB $(\mathrm{g} /$ ekor $)=$ Berat badan akhir $(\mathrm{g})-$ berat badan awal (g)

3. Konversi pakan adalah perbandingan antara jumlah pakan yang dikonsumsi dengan bobot badan yang dihasilkan selama penelitian 
Konversi pakan = Jumlah pakan yang dikonsumsi (g/ekor) / berat badan (g/ekor)

\section{Analisis Data}

Data dianalisis dengan analisis ragam (ANOVA) dan jika terdapat perbedaan antar perlakuan maka dilanjutkan dengan uji Duncan's (Steel dan Torie, 1993).

\section{HASIL DAN PEMBAHASAN}

Rataan konsumsi ransum, pertambahan bobot badan dan konversi pakan pada ayam broiler yang diberi ekstrak jeringau merah pada air minum disajikan pada Tabel 1. Pemberian ekstrak jeringau dalam air minum tidak berpengaruh $(\mathrm{P}>0,05)$ terhadap konsumsi pakan. Rataan konsumsi pakan tertinggi terdapat pada perlakukan $\mathrm{P}_{5}$ sebesar $2607,23 \pm 53,71 \mathrm{~g}$ dan terendah terdapat pada ayam perlakuan P2 sebesar $2540,27 \pm 62,38$ g. Walaupun secara statistik tidak ada perbedaan konsumsi pakan antar perlakuan tetapi pemberian ekstrak jeringau merah memiliki rataan nilai konsumsi ransum yang lebih lebih baik dibandingkan kontrol positif(P1) dan kontrol negatif(P2). Peningkatan konsumsi pakan ini karena kandungan flavonoid yang tinggi pada jeringau merah dimana Sofyan et al. (2017) melaporkan kandungan flavonoid pada rimpang jeringau merah sebesar sebesar $33,76 \%$ b/b. Flavonoid sebagai antibakteri menghambat pertumbuhan bakteri Salmonella typhimurium dalam saluran pencernaan unggas sehingga menyebabkan peningkatan konsumsi pakan ayam broiler. Fru-Nji et al. (2007) menambahkan flavonoid pada unggas berfungsi menambah nafsu makan. Penelitian Langeroudi et al. (2008) melaporkan pemberian Ziziphora clinopodioides (jenis legum yang memiliki senyawa antibakteri) sebanyak $15 \mathrm{~g} / \mathrm{kg}$ dalam pakan cenderung meningkatkan konsumsi pakan dibandingkan dengan ransum kontrol.

Tabel 1. Rataan konsumsi pakan, pertambahan bobot badan, dan konversi pakan, pada ayam broiler

\begin{tabular}{cccc}
\hline Perlakuan & Konsumsi pakan $(\mathrm{g})$ & $\mathrm{PBB}(\mathrm{g})$ & Konversi Pakan \\
\hline $\mathrm{P}_{1}$ & $2552,56 \pm 87,05$ & $1812,36 \pm 47,12$ & $1,40 \pm 0,04$ \\
$\mathrm{P}_{2}$ & $2540,27 \pm 62,38$ & $1792,56 \pm 37,86$ & $1,41 \pm 0,08$ \\
$\mathrm{P}_{3}$ & $2560,35 \pm 18,13$ & $1839,78 \pm 58,65$ & $1,39 \pm 0,07$ \\
$\mathrm{P}_{4}$ & $2572,17 \pm 32,37$ & $1856,54 \pm 89,43$ & $1,38 \pm 0,18$ \\
$\mathrm{P}_{5}$ & $2607,23 \pm 53,71$ & $1844,61 \pm 48,72$ & $1,41 \pm 0,06$ \\
\hline
\end{tabular}

Rataan pertambahan berat badan pada ayam broiler yang diberi perlakuan ekstrak jeringau merah melalui air minum menunjukkan hasil yang tidak berbeda antar perlakuan $(\mathrm{P}>0,05)$. Rataan pertambahan berat badan ayam broiler dapat dilihat pada Tabel 1. Rataan pertambahan berat badan tertinggi terdapat pada perlakuan $\mathrm{P} 4$ dengan nilai sebesar $1856,54 \pm 89,43 \mathrm{~g}$.
Tingginya pertambahan berat badan ayam broiler yang diberi ekstrak jeringau merah karena penyerapan zat pakan yang baik untuk pertumbuhan dan pembentukan jaringan yang disebbakan kandungan senyawa aktif dalam jeringau merah. Senyawa aktif jeringau merah khususnya flavonoid yang tinggi dapat menghambat pertumbuhan bakteri patogen pada ayam yang telah diinfeksi dengan bakteri Salmonella typhimurium. Ulfa dan Natsir (2008) melaporkan penambahan ekstrak daun sambiloto sebesar 0,4\% pada pakan dapat meningkatkan pertambahan bobot badan ayam sebesar 8,82\% dibandingkan dengan kontrol karena daun sambiloto mengandung senyawa aktif diantaranya flavonoid, glikosida, saponin dan andrographolide.

Kandungan senyawa antibakteri flavonoid, alkaloid, terpenoid dan saponin pada ekstrak jerigau merah (Sofyan et al., 2017) mengakibatkan meningkatnya pertambahan bobot badan ayam broiler yang disebakan karena penyerapan zat makanan yang meningkat akibat permeabilitas mukosa usus yang meningkat serta terhambatnya pertumbuhan bakteri patogen (Smithard, 2002; Esimone et al., 2006). Bakteri patogen yang merugikan dalam saluran pencernaan ayam broiler dapat dibunuh oleh senyawa aktif yang terkandung dalam jeringau merah, sehingga nutrisi yang terkandung dalam ransum dapat diserap dengan optimal oleh saluran pencernaan sehingga saluran pencernaan ayam broiler bekerja lebih baik dengan pemanfaatan pakan lebih efisien sehingga dapat meningkatkan pertambahan bobot badan.

Konversi pakan yang semakin tinggi menunjukan pakan yang diberikan tidak efisien (Bestari et al., 2005). Pemberian ekstrak jeringau dalam air minum tidak berpengaruh $(\mathrm{P}>0,05)$ terhadap konversi pakan dengan rataan nilai konversi pakan sebesar 1,38-1,41. Secara statistik tidak ada perbedan nilai konversi pakan pada penelitian ini tetapi pada perlakuan pemberian ekstrak jeringau merah ( $\mathrm{P}_{3}$ dan $\left.\mathrm{P}_{4}\right)$ memiliki rataan konversi pakan terendah diantara perlakuan. Hasil ini sesuai penelitian Ulfa dan Natsir (2008) pemberian ekstrak daun sambiloto sebesar 0,4\% cenderung menurunkan nilai konversi ransum sebesar 4,48\% dibandingkan dengan kontrol karena tanaman yang mengandung senyawa antibakteri dapat meningkatkan penyerapan dalam saluran pencernaan sehingga efisiensi penggunaan ransum menjadi lebih baik (Kamel, 2001).

Kandungan senyawa aktif flavonoid yang terdapat dalamjeringaumerahmampumembentukikatandengan fosfolipid yang terkandung dalam dinding sel bakteri sehingga menghambat pertumbuhan bakteri patogen seperti Salmonella typhimurium (Soetanto, 2005). Flavonoid merupakan senyawa fenol antimikroba yang bersifat desinfektan dan bakteriostatik yang bekerja dengan cara mendenaturasi protein dan membentuk 
senyawa kompleks terhadap protein ekstraseluler yang dapat mengganggu integritas membran dan dinding sel dan aktifitas metabolisme sel bakteri berhenti (Guevara et al., 1999). Adanya zat aktif tersebut dalam tubuh ayam dapat meningkatkan pertambahan bobot badan dan konsumsi ransum sehingga mempengaruhi konversi pakan lebih baik dari ayam yang tidak diberi perlakuan ekstrak jeringau merah.

Alkaloid, terpenoid, dan saponin merupakan senyawa aktif lain yang terdapat dalam jeringau merah yang bersifat antimikroba sehingga mampu membunuh mikroba yang merugikan dalam saluran pencernaan dan mikroba yang menguntungkan dapat meningkat. Dengan demikian peluang penyerapan zat makanan dapat lebih optimal sehingga berdampak pada peningkatan pertumbuhan ayam. Meningkatnya pertumbuhan ayam menyebabkan kebutuhan zat makanan juga semakin meningkat untuk menunjang pertumbuhan yang cepat tersebut sehingga konsumsi ransum meningkat, hal ini karena dalam jeringau merah terdapat zat yang mampu menghambat pertumbuhan bakteri patogen dalam saluran pencernaan (Wiryawan et al., 2005) sehingga penambahan ektrak jeringau merah pada air minum dapat meningkatkan konsumsi pakan pada ayam broiler yang lebih baik dengan menghasilkan pertambahan berat badan yang tinggi dan konversi ransum yang rendah diantara perlakuan.

\section{SIMPULAN}

Penambahan ekstrak jeringau taraf $1 \mathrm{ml} / \mathrm{kg}$ berat badan pada air minum dapat digunakan sebagai pengganti antibiotik karena tidak berpengaruh terhadap pertambahan berat badan dan efisiensi penggunaan pakan.

\section{DAFTAR PUSTAKA}

Bestari, J., A. Parakkasi dan S. Akil. 2005. Pengaruh pemberian tepung daun mengkudu yang direndam air panas terhadap penampilan ayam broiler. Bogor: Prosiding Seminar Nasional Teknologi Peternakan dan Veteriner. 703-713.

Donado-Godoy, P., I. Gardner, B.A. Byrne, M. Leon, E. Perez-Gutierrez, M.V. Ovalle, M. A. Tafur and W. Miller. 2012. Prevalence, risk factors, and antimicrobial resistance profiles of salmonella from commercial broiler farms in two important poultryproducing regions of Colombia. Journal of Food Protection. 75(5):874-883.

Esimone, C.O., I.R. Iroha, E.C. Ibezim, C.O. Okeh and E.M. Okpana. 2006. In vitro evaluation of the interaction between tea extracts and penicillin $\mathrm{G}$ against Staphylococcus aureus. Afr. J. Biotechnol.
5 (11): 1082-1086.

Fru-Nji, F., E. Niess and E. Pfeffer. 2007. Effect of graded replacement of soybean meal by faba beans (Vicia faba L.) or field peas (Pisum sativum L.) in rations for laying hens on egg production and quality. J. Poultry Sci. 44: 34-41.

Gama, N.M.S.Q., A. Berchieri and S.A. Fernandes. 2003. Occurrence of Salmonella sp in laying hens. Brazilian Journal of Poultry Science. 5(1): 15-21.

Guevara,. A.P., V. Carolyn., H. Sakurai,.Y Fujiwara and K. Hashimoto. 1999. An Antitumor or Promoter From Moringa oleifera. Department of Biochemistry. Kyoto Prefectural University of Medicine. Japan.

Habrun, B., B. Šimpraga, G. Kompes and F. Krstulović. 2012. Antimicrobial resistance and serotyping of Salmonella enterica subsp. enterica isolated from poultry in Croatia. Veterinarski Arhiv. 82 (4): 371-381.

Im, C.M., S.J. Jeong, Y.K. Kwon, O.M. Jeong, M.S. Kang and Y.J. Lee. 2015. Prevalence and characteristics of Salmonella spp. isolated from commercial layer farms in Korea. Poultry Science. 94(7):1691-1698.

Kamel, C. 2001. Tracing Modes Of Action And The Roles Of Plants Extracts In Non Ruminants. dalam : P. C. Garnsworthy and J. Wiseman. Nottingham (Editor). Animal Nutrition. University Press, Nottingham.

Langeroudi, A.G., S.M.M. Kiaci, M. Modirsanei, B. Mansouri and A.S. Estabragh. 2008. Comparison of chemical and biological growth promoter with two herbal natural feed additives on broiler chick performance. J. of Animal and Veterinary Advances. $7(5): 570-574$.

Musa, H.H., S.L. Wu, C.H. Zhu, H.I. Seri and G.Q. Zhu. 2009. The potential benefits of probiotics in animal production and health. Journal of Animal and Veterinary Advances 8 (2): 313-321.

Perić, L., D. Žikić and M. Lukić., 2009. Application of alternative growth promoters in broiler production. Bio An Hus J 25(5-6-1):387-397.

Purwaningsih. 2009. Budidaya dan Pengembangan Jeringau Merah (Acorus sp.) Endemik Kalimantan Barat sebagai Fitofarmaka Imunostimulan. Laporan Penelitian Dana DIPA UNTAN. Pontianak.

Smithard, R. 2002. Secondary plant metabolites in poultry nutrition. Dalam : J. M. Mc.Nab and K.N. Boorman (Editor). Poultry Feed Stuffs Supply, Composition and Nutritive Value. CABI Publishing, New York.

Soetanto, H. 2005. Potensi Tanaman Kelor (Moringa oleifera) sebagai Sumber Pakan dan Pangan di Indonesia. Proceeding Seminar AINI V. Universitas Brawijaya. Malang.

Sofyan, A., E. Widodo dan H. Natsir. 2017. Komponen bioaktif, aktivitas antioksidan dan profil asam lemak 
ekstrak rimpang jeringau merah (Acorus sp) dan jeringau putih (Acorus calamus). Jurnal Teknologi Pertanian Vol. 18 No. 3. Desember 2017. 173-180.

Steel, R. G. D. dan J. H. Torrie., 1993. Prinsip dan Prosedur Statistika, Suatu Pendekatan Biometrika. Edisi Kedua. Terjemahan: Bambang Sumantri. Gramedia Pustaka Utama. Jakarta.

Ulfa, M. dan M. H. Natsir. 2008. Penggunaan Sambiloto (Andrographis panisulata $\mathrm{N}$ ) sebagai pakan tambahan untuk memperbaiki performa ayam broiler. J. Ilmu-Ilmu Peternakan Brawijaya. 18(1):11-24.

Windisch, W., K. Schedle., C. Plitzner and A. Kroimayr., 2007. Use of phytogenic products as feed additives for swine and poultry. J Anim Sci. 86:140-148.

Wiryawan, K. G., S. Suharti dan M. Bintang. 2005. Kajian antibakteri temulawak, jahe dan bawang putih terhadap Salmonella typhimurium serta pengaruh bawang putih terhadap performans dan respon imun ayam pedaging. Media Peternakan 22: 52-62. 